\title{
Relationships between ten-year trends of tropospheric ozone and temperature over Taiwan
}

\author{
Kuang-Jung Hsu* \\ No. 1, Section 4, Roosevelt Road, Department of Atmospheric Sciences, National Taiwan University, Taipei, Taiwan
}

Received 7 January 2006; received in revised form 14 December 2006; accepted 2 January 2007

Available online 6 February 2007

\begin{abstract}
The analyses of ten-year ozonesonde observations from 1993 till 2002, over Taipei, Taiwan show influences of climate change. Despite huge increases in its precursor emissions in this region, there were little variations in tropospheric ozone. Results indicate a warmer troposphere, a statistically insignificant rising tropopause, $79 \pm 206 \mathrm{~m}$ per decade, and decreasing tropopause temperature at $-1.0 \pm 0.89 \mathrm{~K}$ per decade. The derived mean tropospheric ozone is $40.58 \pm 10.99 \mathrm{DU}$, and has a statistically insignificant small trend of $-0.78 \pm 1.7 \mathrm{DU}$ per decade. The derived ten-year vertical trends of temperature and ozone are inversely correlated with each other from the middle troposphere up to the lower stratosphere. The averaged monthly vertical temperature trends show a generally warmer middle troposphere. The tropospheric ozone monthly trend has small increases only in the lower troposphere during winter and spring. Strong decreases occur in summer, from the surface up into the stratosphere. For ozone variation, results suggest that influences of climate forcing are stronger than those from precursor increases. More frequent and/or intense convection in summer and other climate-induced effects may contribute to the less than expected ozone observed in the troposphere.
\end{abstract}

(C) 2007 Elsevier B.V. All rights reserved.

Keywords: Tropopause trends; Tropospheric ozone; Ozone; Temperature profiles; Climate forcing

\section{Introduction}

Ozone is one of the most important species in the atmosphere. The presence of ozone shields life from the harmful solar ultraviolet radiation. Reaction between water and $\mathrm{O}\left({ }^{1} \mathrm{D}\right)$ from ozone photolysis is the major source generating hydroxyl radicals, $\mathrm{OH}$, the strongest oxidizing agent. Since $\mathrm{OH}$ reacts with almost all chemicals, ozone indirectly controls the distributions and lifetimes of other species (Staehelin et al., 2001).

\footnotetext{
* Tel.: +886 22367 6474; fax: +88622363 3642 .

E-mail address: kjhsu@ntu.edu.tw.
}

It is known that substantial amounts of tropospheric ozone are transported downward from the stratosphere (Fabian and Pruchniewicz, 1977). High ozone concentrations in remote areas are attributed to the long-range transport of ozone precursors (Fishman and Crutzen, 1978; Liu et al., 1980). Results from TRACE-A, TRACE-P experiments indicate the importance of biomass burning in providing ozone precursors (Thompson et al., 1996; Oltmans et al., 2004). Jacob et al. (1999) found tropospheric chemistry in the Asian Pacific region affecting ground ozone level in the American Midwest. Ozone precursors and the Asian dust can be transported to California, USA in late winter and early spring (Blake et al., 1999). In addition, changes in meteorological 
parameters play a dominant role in ozone variations (Krishnamurti et al., 1993; Chandra et al., 1998).

Many past studies (Oltmans et al., 2006; Logan et al., 1999; Randel et al., 1999) focused on tropospheric ozone, derived highly variable and region specific trends. Oltmans et al. (2006) investigated the longterm tropospheric ozone trend using both surface and ozonesonde sites. In the N.H., the overall change is small. Continental Europe and Japan showed significant increases in the 1970s and 1980s, then leveled off or declined in the more recent decades. Logan et al. (1999) found similar results for 1970-1996. Trends for 1980 1996 differ from those for 1970-1996. All but one European station show zero or negative trends. Increasing trends at the Japanese stations either slowed or are close to zero. US stations show zero or slightly negative trends in tropospheric ozone after 1980. Ten ozonesonde stations between $36 \mathrm{~N}$ to $59 \mathrm{~N}$ analyzed by Randel et al. (1999) show negative trends at all altitudes between 12 and $25 \mathrm{~km}$ for 1979 to 1996 . Tarasick et al. (2005) reanalyzed data from the Canadian ozonesonde stations. Trends are primarily negative between 1980 and 2001, but become positive if data for 1991-2001 is considered alone.

It is known that $\mathrm{O}+\mathrm{O} 2+\mathrm{M}$ is the only reaction producing ozone (DeMore et al., 1997). In the stratosphere, atomic oxygen is formed by photo-dissociation of molecular oxygen, while photolysis of nitrogen dioxide is the main source providing $\mathrm{O}$ in the troposphere. Hydrocarbon assisted NO oxidation reactions become rate-determining steps for tropospheric ozone formation. Over the last three decades, the western Pacific region not only has the most rapid population growth, it also creates the fastest growing economies. The rate of energy consumption in this area is the highest in the world (IEA, 2005), and the emission of ozone precursors is expected to rise accordingly. Therefore, the Asian Pacific region should observe the strongest increase in tropospheric ozone since it has the highest economic growth rate (DiNunno et al., 2003; Oltmans et al., 2004). Due to dramatic increases in key precursor emissions, the Intergovernmental Panel on Climate Change (IPCC, 2001, p7) suggested a $36 \%$ increase in global tropospheric ozone since the industrial revolution.

DiNunno et al. (2003) using datasets from 10-flight observations in twenty years studied the northeastern Pacific region. From observations made in the spring and fall, they found significant ozone decrease between the surface and $4 \mathrm{~km}$, with a small ozone increase at higher levels. Their results differ from the results of two previous intensive observations in the Pacific region, PEM-West $\mathrm{A}$ in the fall and PEM-West $\mathrm{B}$ in the spring.
No significant ozone trend was observed in PEM-West A, while increases in all heights were shown in PEMWest B. DiNunno et al. (2003) suggested that ozone variations are limited around the edge of the Asian continent.

Taiwan, situated between the Asian continent and the Pacific Ocean, experiencing air from both continent and ocean, is an ideal place to examine the possible ozone change. This study presents the first analyses of ozonesonde data for ten years over Taipei $(25.05 \mathrm{~N}$, 121.5E), Taiwan. Unlike most previous studies focusing on the impact of changing ozone on climate, possible impacts from climate variation on ozone distributions will be discussed.

\section{Data analysis}

Data used in this study were collected by the Central Weather Bureau of Taiwan every other week at Taipei since May 1991. An electrochemical cell by EN-SCI (ECC6A) with $1 \% \mathrm{KI}$ buffered solution is used to measure the ozone profile, accompanied by a standard radiosonde (Vaisala RS80-15GE) for pressure and temperature measurement. Only profiles reaching $18 \mathrm{~km}$, about $75 \mathrm{hPa}$, and beyond are considered in this study. Both the cathode $(1 \% \mathrm{KI})$ and anode solutions are prepared every 3 months. Pump pressure, vacuum, pump current, and solution conditions are checked three to seven days before the flight, with the TSC-1 Ozonizer Test Unit (Komhyr, 1986).

Background current, $I_{\mathrm{o}}$ and background pressure, $P_{0}$ are measured right before launch, with ozone destruction filter attached to the air inlet. Based on $I_{\mathrm{o}}, P_{0}$ at ground level, current corrections at other pressure levels, $I_{\mathrm{BG}}$, are made through equation $I_{\mathrm{BG}}=I_{\mathrm{O}} \times(\mathrm{A} 0+\mathrm{A} 1 \times P+$ $\left.\mathrm{A} 2 \times P^{2}\right) /\left(\mathrm{A} 0+\mathrm{A} 1 \times P_{0}+\mathrm{A} 2 \times P_{0}^{2}\right)$, where $P$ is the ambient pressure. Sonde is rejected, if background current is $>0.1 \mu \mathrm{A}$, or negative; vacuum is $<14$ in of $\mathrm{Hg}$; pump current is $>120 \mathrm{~mA}$. There are no changes in sounding instrument and preparation procedure during the tenyear measurement period.

According to Santer et al. (2003), influences from Mountain Pinatubo eruption lingered till part of 1993. In order to exclude contaminated data, the null hypothesis was assumed in testing data distributions between different periods. We reject the hypothesis if the chisquare $\left(\chi^{2}\right)$ statistics between two series is larger than the critical number at a desired significance level, 0.05 in this study. Otherwise, these two series are essentially the same. Results from repeated tests indicate that the dataset starting April 1993 has the same distribution as datasets for the rest of the period. Therefore, only data 

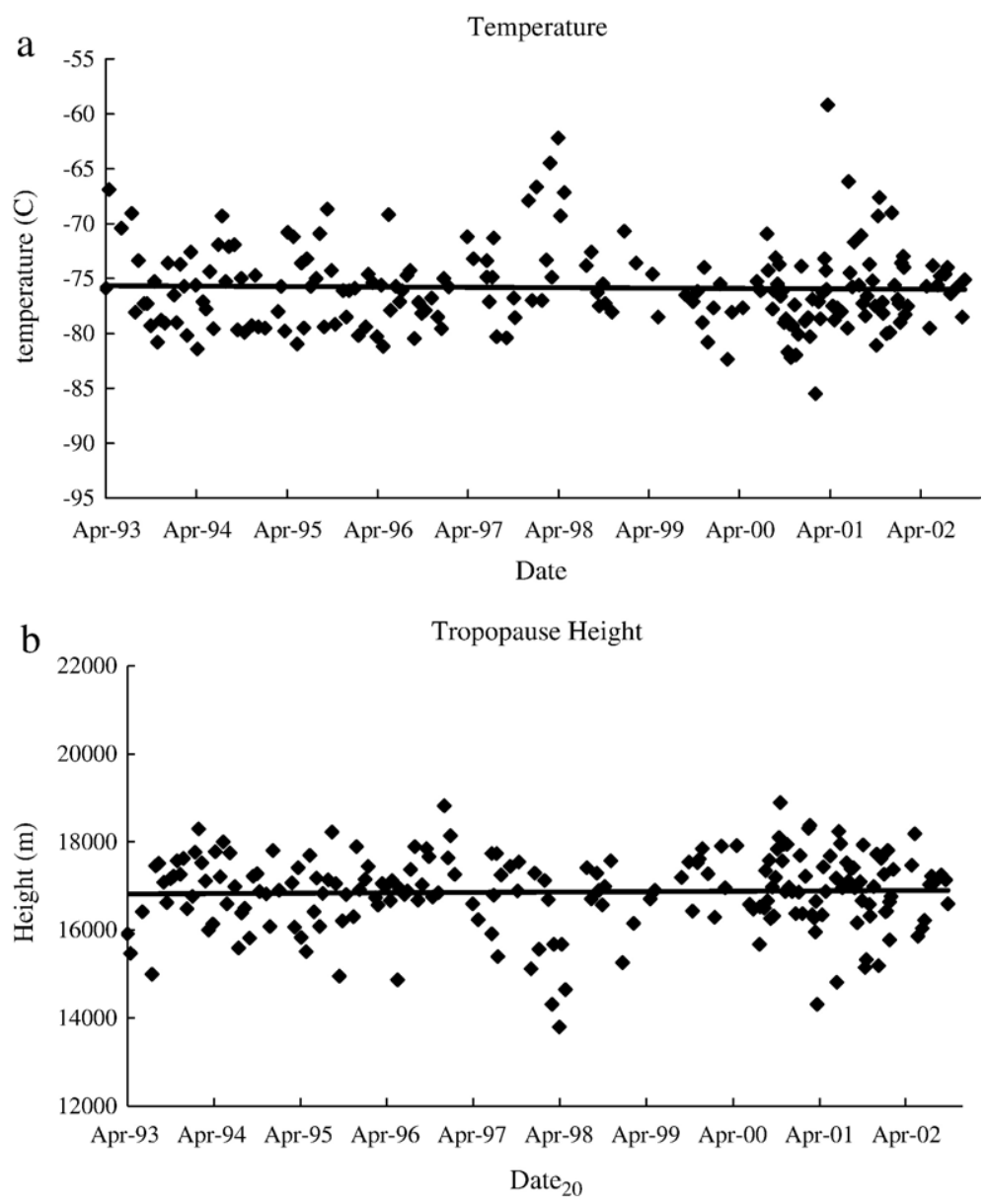

Fig. 1. Tropopause temperature (a) and height (b) derived between April 1993 and October 2002.

collected from April 1993 till October 2002 were used in this analysis. There are a total of 202 successful sounding data. Since not every sounding succeeded in reaching the stratosphere, these data do not have uniform sampling frequency. Tarasick et al. (2005) estimated the linear trend with different adjustments made to the data used. They found some differences, but the overall pattern of trends is similar for these cases. Therefore, trends in the following discussions are derived using a simple linear least square analysis with uncertainties of one standard deviation.

In order to check measurement quality, sounding results were compared with total ozone from satellite observations. Since ozonesondes cover only part of the atmosphere, the missing ozone fraction has to be restored. In this study, ozone partial pressure was first integrated till 7 mbar. The monthly climatological ozone values, ranging from 32.7 to $35.4 \mathrm{DU}$, from McPeters, Labow, and Johnson (1997) are added to each observation to give the integrated plus residual column ozone.
On average, sounding measurements cover $86.4 \pm 1.3 \%$ the resulting total ozone. There are a total of 119 days having satellite pass-bys, and the ratio between the sounding plus residual ozone value and satellite ozone is $0.966 \pm 0.053$.

An earlier study (Hsu and Yung, 1999), using 14 years of TOMS data, found that both natural and anthropogenic variations contribute to total ozone changes over Taiwan. Anthropogenic influence is less important than those from natural variations such as the quasi-biennial oscillation (QBO) and solar cycle, but the ENSO effects are negligible. Hsu and Yung (1999) derived a 29-months period for the QBO over Taipei, Taiwan using multivariate time series analyses. The duration of this study covers nearly four complete cycles of QBO. The influences from the QBO were assumed to cancel out, but contributed larger uncertainties in observed dataset. However, this measurement period coincides with increasing solar activities. It is estimated that this level of solar activity increase produces 5.6 DU 
additional ozone. Majority of this influence occurs in the upper stratosphere, and was not considered in this study.

\section{Results and discussion}

\subsection{Changes in tropopause height and tropospheric ozone}

The locations of the tropopause are identified based on the WMO (1957) thermal definition: the lowest boundary of a layer in which the temperature lapse rate is less than $2 \mathrm{~K} / \mathrm{km}$ for a depth of at least $2 \mathrm{~km}$. In this study, tropopause location was individually identified for each sounding. The resulting ten-year averaged tropopause height is $16.81 \pm 0.86 \mathrm{~km}$, which corresponds to $96 \pm 15 \mathrm{hPa}$. The monthly average tropopause heights and corresponding temperatures indicate a clear negative correlation with each other. The lowest tropopause height occurs in April and the highest in November. The results are in good agreement with derived climatological values by Seidel et al. (2001) between 1961 and 1990.

Tropopause height increases at an insignificant rate of $79 \pm 206 \mathrm{~m}$ per decade, or $-1.1 \mathrm{hPa}$ per decade. Its temperature shows a small decreasing trend, $-1.0 \pm$ $0.89 \mathrm{~K}$ per decade. Both results are shown in Fig. 1(a) and (b). Those numbers are in good agreement with $-1.13 \mathrm{hPa}$ per decade derived from ECMWF reanalysis by Santer et al. (2003), but smaller than the rate of $-2.16 \mathrm{hPa}$ per decade from NCEP reanalysis.

Values of tropospheric column ozone (TCO) are obtained by integrating individual soundings up to the tropopause. The resulting ten-year mean is $40.58 \pm$ 10.99 DU. Except the months of April with the highest value and November the lowest, the values of tropospheric ozone are almost the same. The mean TCO value is higher than the, $31.85 \pm 10.46 \mathrm{DU}$, derived

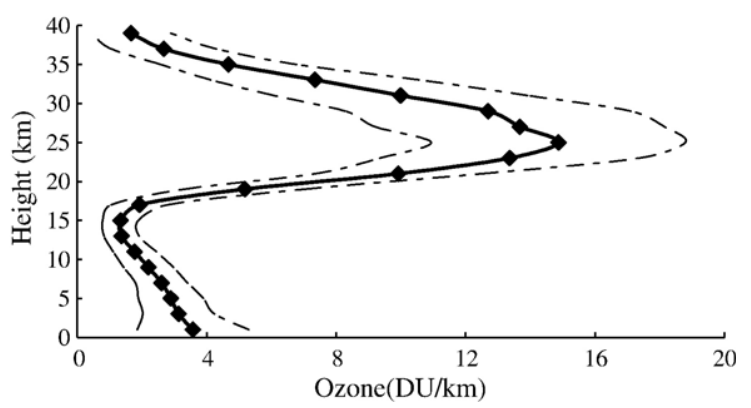

Fig. 2. The averaged ozone profile over Taipei, Taiwan, derived from ozonesonde measurements from April 1993 to October 2002. Dashed lines mark the range of one standard deviation.

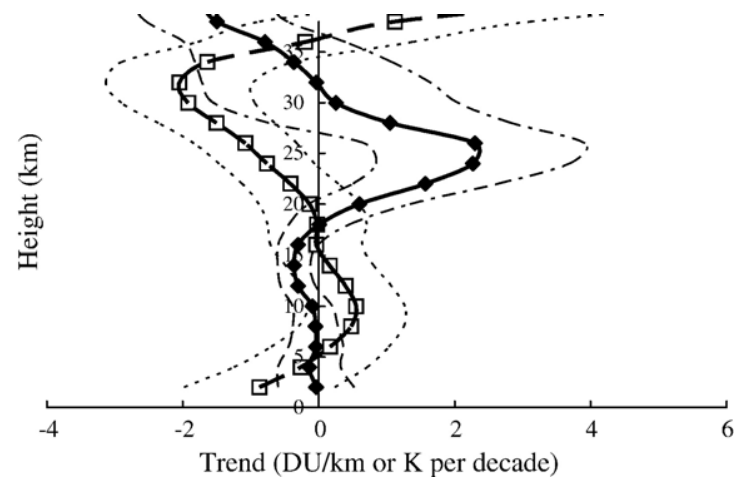

Fig. 3. Trends of ozone (diamond) and temperature (square) derived from ten-year ozonesonde measurement over Taipei. Both curves are results of 5-level centered moving averages. Dotted lines mark the ranges of one standard deviation of both vertical trends.

from Hilo $(19.57 \mathrm{~N}, 155.06 \mathrm{~W})$, USA, but similar to $41.43 \pm 13.77$ DU derived from Kagoshima $(31.58 \mathrm{~N}$, 130.56E), Japan. The latter two datasets were obtained from World Ozone and Ultraviolet Radiation Data Center (WOUDC). Being geographically close to each other may explain the excellent agreement between results from the Japanese site and from this study. Despite rapid increases in ozone precursors emission in this region (IEA, 2005), the tropospheric column ozone shows a statistically insignificant decreasing trend of $-0.78 \pm 1.7$ DU per decade, or $-1.9 \%$ per decade, with deseasonalised data.

\subsection{Trends of vertical profiles}

Each ozone profile was obtained by integrating ozone partial pressures every $2 \mathrm{~km}$, up to $40 \mathrm{~km}$. The results were converted to absolute quantity, DU $\mathrm{km}^{-1}$. The averaged ozone profile is shown in Fig. 2, with one standard deviation. The maximum ozone of $15 \mathrm{DU}$ $\mathrm{km}^{-1}$, about $4 \mathrm{ppm}$, occur between 24 and $26 \mathrm{~km}$ and the minimum value of about $1.3 \mathrm{DU} \mathrm{km}^{-1}, 60$ to $80 \mathrm{ppb}$, are between 12 to $16 \mathrm{~km}$. The temperature profile was derived similarly, except averaging observations every $1 \mathrm{~km}$.

Decadal trends of both temperature and ozone are calculated at each level, shown in Fig. 3. The tropospheric ozone trend shows little change below $10 \mathrm{~km}$, but has a small decreasing trend between 10 and $16 \mathrm{~km}$, with a maximum value of $-0.36 \mathrm{DU} \mathrm{km}^{-1}$ per decade, corresponding to about $-15 \pm 8 \%$ per decade. Variations are larger than $-7.3 \pm 4.6 \%$ per decade by Randel et al. (1999) at $15 \mathrm{~km}$ altitude. Ozonesonde measurements show larger trends between -2 to $-12 \%$ per decade. The altitude range in their study belongs to the lower 

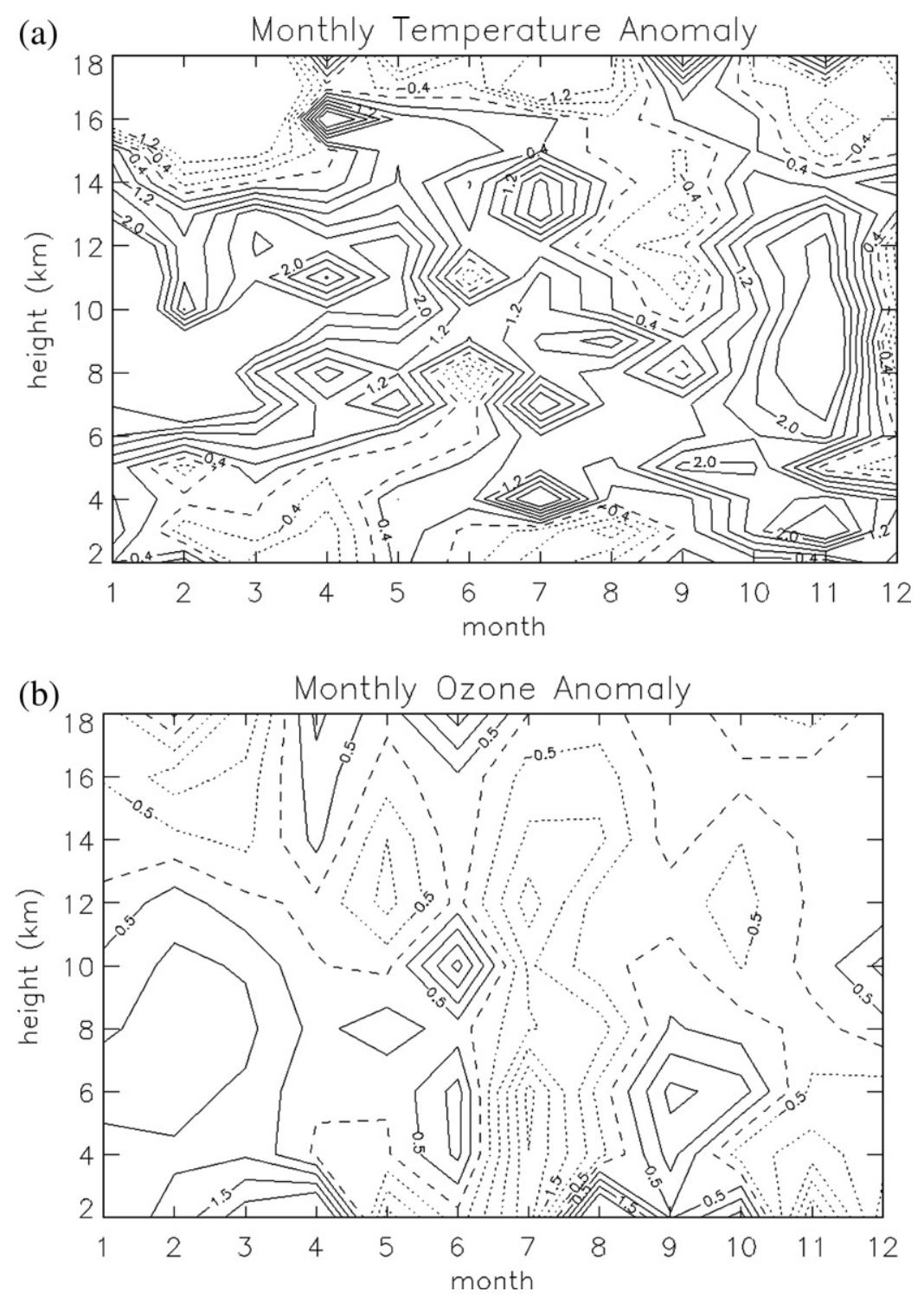

Fig. 4. Ten-year averaged temperature (a) and ozone (b) monthly trends at different height (km) from 1993 till 2002. Contour interval is $0.5 \mathrm{~K}$ per decade or 0.5 DU per decade. Negative values are dotted.

stratosphere, it belongs to the upper troposphere in this study.

Stratospheric ozone exhibits a significant increase between 22 and $26 \mathrm{~km}$, about $12 \pm 6 \%$ per decade. Temperature profiles show a strong warming trend, +0.4 to $+0.5 \mathrm{~K}$ per decade, in the middle to high troposphere, and a stronger cooling trend, about $-2 \mathrm{~K}$ per decade, in the lower stratosphere. The variation of temperature trend is larger than those suggested by early reviews (Ramaswamy et al., 2001; Seidel et al., 2004). No statistically significant relationship was found between trends of ozone and temperature from surface up to
$10 \mathrm{~km}$. These two trends are generally negatively correlated with each other from 10 up to $25 \mathrm{~km}$.

An ascending tropopause was attributed by Zhou et al. (1999) and Santer et al. (2003) to climate warming enhanced frequent and/or more intense convection. The nearly constant ratio of [HDO] to water vapor from the ATMOS experiment (Kuang et al., 2003) suggests the importance of convective process in transporting water into the stratosphere. Due to heavier weight, HDO are more easily condensed than normal $\mathrm{H}_{2} \mathrm{O}$, i.e., isotope fractionation. A deep convection takes little time bringing surface air up to the stratosphere, and there will be 
little differences between $[\mathrm{HDO}] /\left[\mathrm{H}_{2} \mathrm{O}\right]$ at the stratosphere and that at the surface. On the other hand, transport of chemicals to the upper troposphere will take several months time without convections, and there will be a much more depleted [HDO] at the stratosphere, through repeated isotope fractionation.

If only based on rapid increases in precursor emissions, we would expect an increase in tropospheric ozone. Since ozone is the third most important greenhouse gas in the atmosphere (IPCC, 2001, p.7), increasing tropospheric ozone leads to a warmer lower atmosphere. If this phenomenon dominates, both trends of temperature and ozone are expected to have the same sign. Fig. 3 does not support this argument.

Lelieveld and Crutzen (1994) found deep convection affecting ozone lifetime. There will be less ozone produced in polluted areas when more air parcels are lifted to places of less efficient oxidative capacity. Their result suggested that the region between the equator and $30^{\circ} \mathrm{N}$ is an important ozone sink. A study by Wang (2005) over the decreasing PM10 levels in Taiwan for the 1994-2002 period, provided some evidence. His analysis indicated a substantial reduction in close-tosurface inversions, increase in rainfall, and increase in continental outflows.

Stevenson et al. (2000) suggested that a warmer climate increases the atmospheric water content. It accelerates ozone destruction by generating more $\mathrm{OH}$ and $\mathrm{HO}_{2}$, through the faster reaction $\mathrm{O}\left({ }^{1} \mathrm{D}\right)+\mathrm{H}_{2} \mathrm{O}$. In addition, most reaction rate constants are temperature dependent. Rate constants of ozone destruction reactions have either no temperature dependence, $\mathrm{O}(1 \mathrm{D})+\mathrm{H}_{2} \mathrm{O}$, or positive temperature dependence, $\mathrm{O}_{3}+\mathrm{HO}_{2}, \mathrm{O}_{3}+\mathrm{OH}$. The rate constants of the two major $\mathrm{NO}$ oxidation reactions, $\mathrm{NO}+\mathrm{HO}_{2}$, and $\mathrm{NO}+\mathrm{CH}_{3} \mathrm{O}_{2}$ have small negative activation energies (DeMore, 1997). These small temperature effects are generally masked by variations in precursor levels.

Causalities between ozone and temperature variations in the troposphere may work in both directions, and are not mutually exclusive. Increase in the ozone precursors' emissions enhance ozone production, and subsequently lead to a warmer troposphere. This relationship suggests that both variations in temperature and ozone are of the same sign. Climate change affects ozone in many ways. First, a warmer climate creates a wetter atmosphere, which accelerates ozone destruction. Second, a warmer climate may alter the atmospheric dynamic pattern, such as providing more energy for convection, pumping more ozone precursors into the less productive upper troposphere, and reducing the total tropospheric ozone. Third, a warmer troposphere accelerates ozone destruction reactions, resulting in less ozone observed. These possibilities suggest that less ozone is generated as a result of a warmer climate.

These possible relationships evolve with time in different ways. Contour maps of the decadal monthly averaged trends in temperature and ozone at different levels are prepared, as in Fig. 4(a) and (b), to identify major factors. The temperature trend contour plot shows a generally warmer troposphere, except near the surface and upper troposphere. The ozone monthly trend shows more tropospheric ozone in late winter, spring, and late summer. There is a strong decreasing trend in June and July and in the upper troposphere most of the time.

Comparison between these two contour maps found only a portion having trends of the same sign, which suggests the contributions from increasing ozone precursors affects atmospheric temperature. The majority of the maps having trends of opposite signs suggest that climate forcing is more important most of the time. The large ozone decreasing trend, in June and July, reaching the lower stratosphere is probably due to enhanced tropospheric circulations. For the rest of the time, increases in water vapor and/or faster rates of ozone destruction may contribute to the opposite trends in temperature and ozone.

It is also possible that features in Fig. 4(a) and (b) are caused by changes in the flow pattern. An analysis of 9year climatology of airstreams in East Asia by Wang (2005) found that more southerly winds bring cleaner, and warmer air in summer, less northerly winds carry polluted, colder air in winter over Taiwan. His results suggest warmer but less tropospheric ozone where circulation changes occur. Stevenson et al. (2000) using Hadley Center GCM driven STOCHEM chemistrytransport model, predicts a $37 \%$ to $59 \%$ reduction in tropospheric ozone increase when climate change is included. Their results indicate an overall increase in northern hemisphere with the largest increase having occurred from 4 to $10 \mathrm{~km}$. Later study by Johnson et al. (2001) in tropical and subtropical region, calculated a trend of $-0.9 \mathrm{ppb}$ per decade at $650 \mathrm{hPa}$ level with climate change considered. Their value corresponds to about $-0.06 \mathrm{DU} / \mathrm{km}$ per decade, in good agreement with the averaged result below $8 \mathrm{~km},-0.07 \mathrm{DU} / \mathrm{km}$ per decade, derived from this study.

\section{Conclusion}

Several conclusions are derived from this study. First, there is an ascending and colder tropopause, with the troposphere becoming warmer and the stratosphere being cooler. Second, there are statistically insignificant 
decreases in tropospheric ozone. While stratospheric ozone has a sizable increasing trend. Third, the middle to upper troposphere has trends of the same sign in temperature and ozone during late winter and spring. This suggests that precursor increases are a dominant factor affecting ozone distribution, and consequently cause temperature change. However, both trends have opposite signs most of the time. This indicates that climate forcing is a more important factor controlling ozone distribution than the other way around. The strong anti-correlation between these two parameters in June and July may be due to more frequent and/or intense convection in the troposphere. Other climate impacts on tropospheric ozone distributions may also be important, such as changes in atmospheric water content, circulation patterns, or changes in reaction rates. In this study, there is no sufficient information to differentiate these factors. However, this study suggests that climate impacts are strong enough to affect the tropospheric ozone distribution.

It is known that atmospheric ozone is highly variable, and the trends derived in one location may not represent the whole region. The results from this study show how complicated the real system is. Many factors exist simultaneously, in different time, or locations. More studies on long-term vertical variations of temperature, ozone, and other chemicals are needed to further our understandings on the climate change issue.

\section{Acknowledgement}

This author is grateful to Ms. Lo RuHuei for her assistance in ozonesonde instrumentation, and to the Central Weather Bureau of Taiwan and World Ozone and Ultraviolet Radiation Data Center for providing sounding data. Thanks are also due to two anonymous referee, their comments and suggestions substantially improved the readability of this manuscript.

\section{References}

Blake NJ, Blake DR, Wingenter OW, Sive BC, McKenzie LM, Lopez JP, et al. Influence of southern hemisphere biomass burning on mid-tropospheric distribution of non-methane hydrocarbons and selected halocarbons over the remote South Pacific. J Geophys Res 1999; 104:16213-32.

Chandra S, Ziemke JR, Min W, Read WG. Effects of 1997-1998 El Nino on tropospheric ozone and water vapor. Geophys Res Lett 1998;25:3867-70.

DeMore WB, Sander SP, Golden DM, Hampson RF, Kurylo MJ, Howard CJ, et al. Chemical Kinetics and Photochemical Data for Use in Stratospheric Modeling, vol. 97-4. Pasadena, California: JPL publication; 1997.

DiNunno B, Davis D, Chen G, Gregory G, Sachse G, Anderson B, et al. Central/eastern North Pacific photochemical precursor distribu- tions for fall/spring seasons as defined by airborne field studies. J Geophys Res 2003;108. doi:10.1029/2001JD001044.

Fabian P, Pruchniewicz PG. Meridional distribution of ozone in the troposphere and its seasonal variation. J Geophys Res 1977;82: 2063-73.

Fishman J, Crutzen P. The origin of ozone in the troposphere. Nature 1978;274:855-8.

Hsu KJ, Yung YL. Ozone trend over Taiwan from TOMS data. Terr Atmos Ocean Sci 1999;10:619-32.

IEA (International Energy Agency). CO2 Emissions from Fuel Combustion, 1971-2003. Organization of Economic Corporation and Development (OECD); 2005.

IPCC (Intergovernmental Panel on Climate Change). Climate change 2001: the scientific basis. In: Houghton JT, et al, editor. Contribution of Working Group I to the Third Assessment Report of the Intergovernmental Panel on Climate Change. Summary for Policymakers. Cambridge University Press; 2001. p. 7.

Jacob DJ, Logan JA, Murti PP. Effects of rising Asian emissions on surface ozone in the United States. Geophys Res Lett 1999;26: $2175-8$.

Johnson CE, Stevenson DS, Collins WJ, Derwent RG. Role of climate feedback on methane and ozone studied with a coupled OceanAtmosphere-Chemistry model. Geophys Res Lett 2001;28: 1723-6.

Komhyr WD. NOAA Technical Memorandum ERL ARL-149: Operations Handbook - Ozone Measurement to 40-km Altitude with 4A Electrochemical Concentration Cell (ECC) Ozonesondes, 1986.

Krishnamurti TN, Fuelberg HE, Sinha MC, Oosterhof D, Bensman EL, Kumar VB. The meteorological environment of the tropospheric ozone maximum over the tropical South Atlantic Ocean. J Geophys Res 1993;98:10,621-41.

Kuang Z, Toon GC, Wennber PO, Yung YL. Measured HDO/ $\mathrm{H}_{2} \mathrm{O}$ ratios across the tropical tropopause. Geophys Res Lett 2003;30. doi:10.1029/2003GL017023.

Lelieveld J, Crutzen P. Role of deep cloud convection in the ozone budget of the troposphere. Science 1994;64:1759-61.

Liu SC, Kley D, McFarland M, Mahlman JD, Levy II H. On the origin of tropospheric ozone. J Geophys Res 1980;85:7546-52.

Logan JA, Megretskaia IA, Miller AJ, Tiao GC, Choi D, Zhang L, et al. Trends in the vertical distribution of ozone: a comparison of two analyses of ozonesonde data. J Geophys Res 1999;104:26,373-99.

McPeters RD, Labow GJ, Johnson BJ. A satellite-derived ozone climatology for balloonsonde estimation of total column ozone. J Geophys Res 1997;102:8875-85.

Oltmans SJ, Johnson BJ, Harris JM, Thompson AM, Liu HY, et al. Tropospheric ozone over the North Pacific from ozonesonde observations. J Geophys Res 2004. doi:10.1029/2003JD003466.

Oltmans SJ, Lefohn AS, Harris JM, Galbally I, Scheel HE, Bodeker $\mathrm{G}$, et al. Long-term changes in tropospheric ozone. Atmos Environ 2006;40:3156-73.

Ramaswamy V, Chanin ML, Angell J, Barnett J, Gaffen D, Gelman M, et al. Stratospheric temperature trends: observations and model simulations. Rev Geophys 2001;39:71-122.

Randel WJ, Stolarski RS, Cunnold DM, Logan JA, Newchurch MJ, Zawodny JM. Science 1999;285:1689-92.

Santer BD, Sausen R, Wigley TML, Boyle JS, AchutaRao K, Doutriaux C, et al. Behavior of tropopause height and atmospheric temperature in models. Re-analyses, and observations: decadal changes. J Geophys Res 2003;108:ACL 1-1-ACL 1-12.

Seidel DJ, Ross RJ, Angell JK, Reid GC. Climatological characteristics of the tropical tropopause as revealed by radiosondes. J Geophys Res 2001;106:7857-78. 
Seidel DJ, Angell JK, Christy J, Free M, Klein SA, Lanzante JR, et al. Uncertainty in signals of large-scale climate variations in radiosonde and satellite upper-air temperature datasets. J Climate 2004; 17:2225-40.

Staehelin J, Harris NRP, Appenzeller, Eberhard J. Ozone trends: a review. Rev Geophysics 2001;39:231-90.

Stevenson DS, Johnson CE, Collins WJ, Derwent RG, Edwards JM. Future estimates of tropospheric ozone radiative forcing and methane turnover - the impact of climate change. Geophys Res Lett 2000;27:2073-6.

Tarasick DW, Fioletov VE, Wardle DI, Kerr JB, Davies J. Changes in the vertical distribution of ozone over Canada from ozonesondes: 1980 2001. J Geophys Res 2005;110:d02304. doi:10.1029/2004JD004643.
Thompson AM, Pickering KE, McNamara DP, Schoeberl MR, Hudson $\mathrm{RD}$, Kim JH, et al. Where did tropospheric ozone over southern Africa and the tropical Atlantic come from in October 1992: insights from TOMS, GTE/TRACE-A and SAFARI-92. J Geophys Res 1996;101:24,251-78.

Wang KY. A 9-year climatology of airstreams in East Asia and implications for the transport of pollutants and downstream impacts. J Geophys Res 2005;110:D07306. doi:10.1029/2004JD005326.

World Meteorological Organization (WMO). Definition of the tropopause. WMO Bull 1957;6:136.

Zhou XL, Geller MA, Zhang M. Cooling trend of the tropical cold point tropopause temperatures and its implications. J Geophys Res 1999;106:1511-22. 